\title{
Prospects for the Development of Russian Export in the Context of Digitalization
}

\author{
Ekaterina Klimakova $^{1}$ \& Alireza Nasiri ${ }^{2}$ \\ ${ }^{1}$ School of International Economics and Trade, Dongbei University of Finance and Economics, Dalian, China \\ ${ }^{2}$ University of Tehran, Tehran, Iran \\ Correspondence: Ekaterina Klimakova, School of International Economics and Trade, Dongbei University of \\ Finance and Economics, No. 217 JianShan Street, Shahekou District, Dalian 116025, China. E-mail: \\ klimakova_ekaterina@mail.ru
}

Received: June 22, 2020

Accepted: August 15, 2020

Online Published: September 3, 2020

doi:10.5430/rwe.v11n5p114

URL: https://doi.org/10.5430/rwe.v11n5p114

\begin{abstract}
The global trend in digitization has revolution the global economy and the way of doing business in our world currently. The digital trend is instrumental to globalization and specifically international trade. In Russia, the application of digitization is relatively low compared to other emerging economies. Therefore, it becomes interesting to assess the prospects of digitization in increasing export of the country and extensively, if such influence on export is industrial sensitive. To accomplish this, we assessed industrial export of Russia and used panel Autoregressive Distributed Lag (ARDL) technique to determine the impact of digitization on Russia's export. By implementing Mean Group (MG) estimator which was adjudged to be suitable for this model through the Hausman test, it could be revealed that the impact of digitization is more intense in the short-run. The long-run effect is not statistically significant. Based on industries, digitization is significantly responsible for the export of Crude materials, inedible, except fuels; and Machinery and transport equipment in the short-run while also contributes to the long-run increase in export of Beverages and tobacco. The prospect can be increased when the country adapts and adopts more in the global trend.
\end{abstract}

Keywords: digitization, export, panel ARDL, Russia

JEL Classification: C23, F10, O3

\section{Introduction}

One of the drivers of new globalization as noted by Baldwin (2016) includes enhanced digitization and increasing bilateral trade. There is no doubt that digitization has come to stay and is a vector that drives the world economy into a digital economy. But the improvement of the digital industry entails the creation and sustenance of infrastructure supply. Digitization is vital in employment both as a tool and job opportunity (Raja, Imaizumi, Kelly, Narimatsu and Paradi-Guilford (2013) while it has been vital in augmenting economic growth in the process. Many researchers have established that digitization has given way for economic growth in tremendous ways. Datta and Agarwal (2004), Chavula (2013) and Adeleye and Eboagu (2019) reported that in African, even though the rate of appreciation is relatively low, it has contributed enormously and significantly to economic progress. Other researchers believe it has also been instrumental to the employment of women in the society as well as change the overall individual habit (Sovbetov 2018). In Russia particularly, Abramova and Grishchenko (2020) ascertained that the relationship between digitization, productivity and employment is heterogeneous and dependent on the sector of the economy.

In trade literature, Melitz (2003) noted that trade liberalization comes with increasing entry costs to overseas markets, hence, only the most productive firms are efficient enough to cover the cost and enable them to engage in international trade. In recent years, Information and Communication Technologies (ICT) contribute is seen to have contributed to firms' internationalization (Bojnec and Fertö, 2009; Yadav, 2014) by reducing trade costs associated with uncertainty (Abramovsky and Griffi, 2006) as well as increasing the efficiency of the logistics process (World Bank, 2018). The consequence of which is a decreased trade cost and increased international trade flows. Data corroborate the relevance of both ICTs and trade in the new wave of globalization: according to World Bank data, from 2000 to 2014 exports increased from 26.10 to 30.20 as a percentage of GDP, while internet users as a 
percentage of the total population grew from almost 7 to 401 . Correspondingly, in Russia specifically, internet usage as a percentage of the total population has increased from approximately 1.98 per cent in 2000 to 80.86 per cent in 2018 resulting to export increase from US $\$ 105.03$ billion in 2000 to US $\$ 444.01$ billion in 2018 . Would the increase in the percentage of internet users in Russia occasion the rise in export from the country? This paper provides insight.

As the rate of digitization has been appreciating in Russia, the implication on the economy has always be restricted to economic development and unemployment (Garifova, 2014; Abramova and Grishchenko, 2020). The World Bank (2018) reports that Russia adopted its Digital Economy Program in July 2017 and projected annual budget of US $\$ 1.80$ billion until 2025 to address the current weaknesses preventing the country from joining global digital economy leaders. This has contributed to significant economic progress but little has been known on its impact on export trade in the country. Thus providing a research gap which is being portrayed in this research.

Central to this research is the assessment of the potential of digitization as the promoter of Russia's export. This paper becomes relevant given that frontrunner researchers have given little or no attention is this direction making one wonder on the possible influence of digital economy in the face of Russia's export and especially the response of various sectors export in the face of digitization. To accomplish this, we employed a robust approach by adopting dynamic panel Autoregressive Distributed Lag (ARDL) techniques with Mean Group (MG) estimator preferred. The outcome revealed that the overall effect of digitization is more of a short-run phenomenon. While some industries responded positively in the short-run, some few where influence positively in the long-run. Therefore, there is a prospect of digitization influencing Russia's export in recent time and years to come as improvement in application and adaptation is highly recommended.

The rest of the paper is structured as follows: section 2; the literature review which seeks to relay empirical opinions of the earlier researcher in this direction and section 3 which introduces the model, data and estimation technique. Others are section 4 which comprises the estimations and discussion of results and finally the concluding remarks which is mainly in section 5 .

\section{Brief Literature Review}

The Internet is being acknowledged to be the world's largest marketplace, operating transactions for 24 hours a day, seven (7) days a week uninterrupted as well as providing limitless opportunities for buyers and sellers (Lin, 2014). Just as it has been instrumental to the development of some economies (Datta and Agarwal, 2004; Badjar and Rajeev, 2016; and Adeleye and Eboagu, 2019) and welfare of citizens (Chavula, 2013), it has also been influential in workplaces (Raja, et al., 2013) and employment opportunities (Sovbetov, 2018). Digitization is implemented as a working tool in the work environment while boosts new career opportunities and such versatility also contribute to economic growth and development. However, these researches are relevant in their perspective but no contribution to influences on trade which is central to this research.

Lin (2014) noted that adopting internet connectivity will enable suppliers to easily find information about potential new buyers markets and can promote to several potential customers at the same time, thereby lessening the fixed costs of accessing overseas markets. Rauch (1996), Belderbos and Sleuwaegen (1998) and Rauch and Casella (2003) have reported both empirically and theoretically that information cost is an informal trade barrier which raises transaction cost in international trade. In other to alleviate the effect of this cost, Freund and Weinhold $(2002,2004)$ noted that the internet as a search and communication toll has rendered its significant role in ameliorating cost reduction in international trade which concurs to the empirical outcome of Bojnec and Fertö (2009) and Yadav (2014) that the internet, of course, reduces trade costs. In the same vein, Fink et al., (2005) acknowledged that the internet affects both the fixed and variable costs of information exchange between the consumers and suppliers as both incur communications costs. In as much as this researches have highlighted the impact of digitalization on international trade, little has been said on specific reference to Russia federation, besides, while GMM and Pooled OLS dominated the instrument of estimation, they did not consider dynamic approaches like ARDL estimation techniques.

Many types of research have evolved on how digitization is transforming the economy of the Russian Federation ranging from overall economic development to improvement in employment. Prompted by the notion that increasing ICT would result to the displacement of the worker in Russia, Abramova and Grishchenko (2020) ascertain that the relationship between digitization, productivity and employment is heterogeneous and dependent on the industry. On the other hand, Garifova (2014) believes digitization has favoured business improvement as well as the quality of economic growth in Russia. Despite, these impressive impacts of advance technology in Russia, there are still some hindrances towards adopting and adapting to the new technologies. In light of this, Putilov, Pimenova and Timokhin (2018) study the impediment in the use of advance technologies by economic agents in Russia. It noted that 
infrastructure deterrence is one of the key obstacles towards technological market development and reasoned that overhaul of infrastructure timely.

In another dimension, Gromova, Timokhin and Popova (2020) observed that digitization plays a significant role in the advancement of innovative ideas and internationalize small enterprises in Russia. However, it failed to empirical ascertain the prospective impact of digitization in internationalizing these developing enterprises which could be analogous to its impact on Russia's international trade engagement. Again, the method of analysis did not capture a dynamic approach that will be implemented in this research, as well as compressed gravity approach. This still left a big research gap that is been exploited in this paper.

\section{Methodological Notes}

\subsection{Model Specification and Data}

To realize the main objective of this research, this paper will modify an augmented gravity equation by Choi (2010). The equation was used to estimate the impact of digitization on service trade and as such the dependent variable is Service trade (InService). The independent variables included internet usage ( $\left.\operatorname{lnIntt}_{i t}\right)$; and control variables like nominal gross domestic product (GDP) $\left(\ln G D P_{i t}\right)$, population $\left(\ln P O P_{i t}\right)$ and financial depth-broad money per GDP (M2/GDP). The population and GDP were used to capture the market and purchasing ability while financial depth controls for the overall comparative advantage in services. Thus, Choi (2010) model is presented as follows;

$$
\text { lnService }=\beta_{0}+\beta_{1} \operatorname{lnIntt}_{i t}+\beta_{2} \operatorname{lnGDP}_{i t}+\beta_{3} \operatorname{lnPop}_{, i t}+\beta_{4} \ln \left(\frac{M_{2}}{G D P}\right)_{i t}+\sum_{j=1996}^{2006} \text { Year }_{j-1990} \text { Year }_{j}+C_{i}+\mu_{i t}
$$

However, the interest of this research is not trending toward the gravity model but a dynamic panel estimation, as such bilateral service trade will be replaced with industrial export from Russia. The year control for importer (Year $\left.{ }_{j}\right)$ is eliminated since we are dealing on directional trade-export. Finally, we modify Choi (2010) equation to accommodate our purpose with equation 2 represented as follows;

$$
\text { lnTrade }_{i t}=\beta_{0}+\beta_{1} \operatorname{lnGDP}_{t}+\beta_{2} \operatorname{lnIntt}_{t}+\beta_{4} \operatorname{lnFDI}_{t}+\beta_{4} \operatorname{lnGini}_{t}+\mu_{t}
$$

Trade constitutes of nominal export; following Azu (2019) the market size and purchasing ability is proxy with the real GDP; internet penetration rate $\left(\operatorname{lnInt}_{t}\right)$ measured as the percentage of the population is used to capture digitization in Russian Federation. Trade literature has acknowledged that the rate of digitization influences trade positively and as such, it is expected to follow this part in Russia's export. Net Foreign Direct Investment (FDI) is also introduced as an exogenous variable that could control trade flow. Lastly, the Gini coefficient (lnGini $i_{t}$ )is an index aimed at assessing the degree of inequality in a distribution in a country. It measures the country's wealth or income distribution and how it deviates from an equal distribution. The assumption is that the as income is distributed equitably, it will aid export distribution as a more equable distribution of income could be associated with self-reliance. Table 1 constitutes the source of data and a priori expectation.

Table 1. Data sources and expected signs of coefficients

\begin{tabular}{lll}
\hline Variables & Expectation & Sources \\
\hline Export $\left(\right.$ Trade $\left._{t}\right)$ & Dependent & UNCOMTRADE. \\
\hline GDP constant $\left(G D P_{t}\right)$ & Positive $(+)$ & World Development Indicator (WDI) \\
\hline Internet Penetration Rate $\left(I N T T_{t}\right)$ & Positive $(+)$ & World Development Indicator (WDI) \\
\hline Net Foreign Direct Investment $\left(F D I_{t}\right)$ & Positive (+) & World Development Indicator (WDI) \\
\hline Gini Index $\left(\right.$ Gini $\left._{2, t}\right)$ & Positive (+) & World Development Indicator (WDI) \\
\hline
\end{tabular}

UNCOMTRADE- United Nations International Trade Statistics Database.

\subsection{Estimation Technique}

The data for this research is structured in a panel of nine (9) industries (Note 1) covering 23 years from 1996-2018. Therefore, a dynamic estimation technique in panel ARDL is preferred for the analysis. This technique requires that all variables-dependent and independent are stationary at a level or first difference. As such we will adopt Im, Pesaran and Shin (2003) choice of unit root test for panel data, popularly known as Im-Pesaran-Shin (IPS) panel unit-root test.

The panel ARDL estimation technique as proposed by Pesaran and Smith (1995) and Pesaran, Shin, and Smith (1999, 
2001), is dynamic as it takes into consideration the lag of dependent variable as well as that of the independent variables. So, the panel estimation will portray the true impact of digitization on export since the digital application will require lagged period in acclimatizing to a new process, thus, will take some times to replicate its impact on the improvement of export.

However, the application of panel ARDL is anchored on two schools of thought separated by the preference of estimator. On one hand, Pesaran and Smith (1995) suggested use of the Mean Group (MG) estimator to eliminate biases resulting from heterogeneous slopes in dynamic panels while estimating both the short-and long-run coefficients of the variables. The MG estimator provides consistent estimates of the mean of the long-run coefficients but will be inefficient with slope homogeneity. On the other hand, Pesaran et al. $(1999,2001)$ endorse a more efficient estimator for the long-run coefficients which assume homogeneity of each variable in the panel; a Pooled Mean Group (PMG) estimator. This school of thought believes that the use of PMG estimator will allow the short-run parameters to be heterogeneous while the long-run parameters remain homogenous.

However, researchers are often confronted with the problem of choice between the two estimators. In this paper, the Hausman (1978) test will be performed to determine which estimator is most appropriate for the panel. As such the null hypothesis $\left(\mathrm{H}_{0}\right)$ that the MG and PMG estimates are not significantly different; meaning that the PMG is more efficient is determined. The baseline will be to reject the null hypothesis if p-value is less than 0.05 .

Usually, the panel ARDL (p, q, q..., q) model is demonstrated thus;

$$
y_{i t}=\sum_{j=1}^{p} \delta_{i j} y_{i, t-j}+\sum_{j=0}^{q} \beta_{i j} X_{i, t-j}+\gamma_{i}+\varepsilon_{i t}
$$

Where $y_{i t}$ is the dependent variable, $\left(X_{i t}^{\prime}\right)^{\prime}$ is $\mathrm{M}^{*} 1$ vector that is stationary at a level or first difference; $\delta_{i j}$ represents the coefficient of the lagged dependent variable to be estimated; $\beta_{i j}$ is $\mathrm{M}^{*} 1$ coefficient vectors; $\gamma_{i}$ stands for fixed effects such that; $\mathrm{i}=1, \ldots, \mathrm{N} ; \mathrm{t}=1,2, \ldots, \mathrm{T} ; \mathrm{p}, \mathrm{q}$ are optimal lag orders to be determined by estimating the unrestricted model; $\varepsilon_{i t}$ represent the white noise.

The re-parameterized panel ARDL (p, q, q..., q) error correction model for this paper is represented as follows with all variables are in natural logarithm;

$$
\begin{aligned}
& \Delta \text { lntrade }_{i t}=\theta_{i}\left[\text { lntrade }_{i, t-1}-\phi_{i}^{\prime}\left(\operatorname{lnGDP_{i,t}}+\operatorname{lnIntt}_{i, t}+\operatorname{lnFDI_{i,t}}+\operatorname{lnGini}_{i, t}\right)\right]+\sum_{j=1}^{p-1} \lambda_{i j} \text { Intrade }_{i, t-j}+ \\
& \sum_{j=0}^{q-1} \varphi_{i j}^{\prime} \Delta \operatorname{lnGDP_{i,t-j}}+\sum_{j=0}^{q-1} \varphi_{i j}^{\prime} \Delta \operatorname{lnIntt_{i,t-j}}+\sum_{j=0}^{q-1} \varphi_{i j}^{\prime} \Delta \operatorname{lnFDI_{i,t-j}}+\sum_{j=0}^{q-1} \varphi_{i j}^{\prime} \Delta \operatorname{lnGini} i_{i, t-j}+\alpha_{i}+\varepsilon_{i t}
\end{aligned}
$$

Notes: $\theta_{i}=$ coefficient for speed of adjustment to equilibrium which is expected to be less than 0 .

$\phi_{i}^{\prime}=$ Coefficients of long-run relationships

$E C T=\left[\operatorname{lntrade}_{i, t-1}-\phi_{i}^{\prime}\left(\operatorname{lnGDP_{i,t}}+\operatorname{lnIntt}_{i, t}+\operatorname{lnFDI_{i,t}}+\operatorname{lnGini_{i,t})}\right]\right.$ represent the error correction term to be estimated.

$\lambda_{i j}, \varphi_{i j}^{\prime}$ represent the short-run dynamic coefficients

Table 2. Correlation and summary statistics

\begin{tabular}{llllll}
\hline \multicolumn{6}{l}{ Panel A Correlation } \\
\hline Variable & lntrade $_{t}$ & lnGDP $_{t}$ & lnIntt $_{t}$ & lnFDI $_{t}$ & lnGINI $_{t}$ \\
\hline lntrade $_{t}$ & 1 & & & & \\
lnGDP $_{t}$ & 0.346 & 1 & & & \\
lnIntt $_{t}$ & 0.332 & 0.581 & 1 & & \\
lnFDI $_{t}$ & 0.289 & 0.527 & 0.485 & 1 & \\
lnGINI $_{t}$ & 0.0345 & 0.0456 & -0.0694 & 0.328 & 1 \\
\hline Panel B Summary Statistics & & & & \\
\hline Variable & Obs & Mean & Std. Dev. & Min & Max \\
\hline lntrade $_{t}$ & 207 & 22.65762 & 2.051859 & 16.94629 & 26.64226 \\
lnGDP $_{t}$ & 207 & 27.88972 & 0.262689 & 27.42403 & 28.17462 \\
lnIntt $_{t}$ & 207 & 2.549036 & 1.782658 & -1.31025 & 4.392777 \\
lnFDI $_{t}$ & 207 & 23.3786 & 1.190043 & 21.6708 & 25.03786 \\
lnGINI $_{t}$ & 207 & 3.673704 & 0.054402 & 3.605498 & 3.830813 \\
\hline
\end{tabular}

Note: Author's Computation 


\section{Estimation and Results}

Before delving into the analysis of the effect of digitization on Russian export to determine its prospect in the traded sector, we would like to understand the behavior of the data used in the analysis by determining the summary statistics, correlation coefficients and the stationarity of data. The correlation and summary statistics are reported in table 2 with the former in panel A and the later in panel B respectively. There is an indication that no pair of independent variables is reportedly correlated. This eliminates the possibility of having avoidable multicollinearity issues which are usually obvious when estimating equation with pair or more independent variables highly correlated.

Having said that it should be noted from the summary statistics in panel B of Table 2 that the data is a balanced data with a total number of 207 observations in the panel. The panel consists of nine (9) industries at first level, Standard International Trade Classification (SITC) $3^{\text {rd }}$ revision as obtained from UNCOMTRADE. Ascertaining the stationarity level of the data is necessary to determine its suitability for panel ARDL techniques estimation. As noted earlier from the previous section, one basic assumption of ARDL is that all variables are integrated at order one (I1) and therefore, variables are expected to be stationary at a level or first difference. The unit root test is conducted following IPS technique for panel data. The result of the estimation is summarized in table 3, which specifies that all variables are at least stationary at first difference. While Russian export, GDP, Net FDI and Gini Index are stationary at the first difference, internet subscription which is used to proxy digitization is stationary at level. Thus it echoes that the equation is suitable for estimation with panel ARDL technique.

On the other hand, to determine the appropriate estimator suitable for the panel, I decide between the MG estimator and PMG with the Hausman test. Testing for the null hypothesis of homogeneity between MG and PMG estimators, the p-value is established to be less than 0.05 (see appendix I). Therefore, the hypothesis of homogeneity is rejected, thus favoring the use of MG estimator for estimating the model. This suggests that the MG estimator is more reliable and efficient in this scenario.

It should be noted that the choice of lag could influence the outcome of ARDL result since different outcome emanates from difference lag choices. To avoid biases in choice of lag, we have estimated the unrestricted model and resolve on the optimal of lags for each variable per industry. The estimation reflects that the optimal lag is $1,2,0,2,0$ for export, real GDP, internet penetration rate, FDI and Gini Index respectively.

Table 3. Unit Root Test (IPS)

\begin{tabular}{llllll}
\hline & Level & \multicolumn{3}{c}{ 1st Difference } & Remark \\
\hline Variable & Constant & Trend & Constant & Trend & \\
\hline lntrade $_{t}$ & 1.0738 & 0.0209 & $-6.5167 * * *$ & $-4.9369 * * *$ & I1 \\
lnGDP $_{t}$ & 0.0933 & 3.8819 & $-5.7471^{* * *}$ & $-9.0340^{* * *}$ & I1 \\
lnIntt $_{t}$ & $-7.2474 * * *$ & 4.6590 & -0.9166 & $-6.1607 * * *$ & I0 \\
$\operatorname{lnFDI}_{t}$ & 0.3300 & 4.1107 & $-7.7737 * * *$ & $-7.3789 * * *$ & $\mathrm{I} 1$ \\
$\operatorname{lnGINI}_{t}$ & -0.3696 & 2.2093 & $-3.9157^{* * *}$ & $-2.1040^{* *}$ & $\mathrm{I} 1$ \\
\hline
\end{tabular}

Note: Numbers in the display are t-statistics generated with lag $1 . * * * \mathrm{p}<0.01, * * \mathrm{p}<0.05, * \mathrm{p}<0.1$; Null hypothesis $\left(\mathrm{H}_{0}\right)$ : the series has a unit root. Constant-constant only \& Trend-constant and Trend

\subsection{Effects and Prospects of Digitization on Russian Export}

Following the MG estimator, the coefficient of error correction term $(E C T)$ indicates there is cointegration. Meaning a long-run relationship exists between the dependent variable and independent variables in the model. The $E C T$ also specifies the speed of error correction. According to Sovbetov (2018) and Sovbetov and Saka (2018), the coefficient of ECT ranges between -1 and 0 . The estimated coefficient of ECT suggests that the model is without any issue relating to serial error correction and possible instability originating from a structural break in the panel data. From table 4, the magnitude of ECT is $/ 0.33$ / which demonstrate that the movement toward equilibrium corrects at the speed of 33 per cent annually. Therefore, it suggests a slow convergence rate which necessitates a loose cointegration in the panel.

The concept of digitization has been influential in the development of the world economy while also it has been instrumental in bilateral trade. In Russia, the effect of digitization on export is much felt in the short-run. The panel 
ARDL estimation reveals that in the short-run, the coefficient for the overall impact of digitization on Russian export is 0.0742 and statistically significant at 10 per cent (see table 4). This implies that digitization will reduce the cost of trade in the Russian Federation by 7.42 per cent ceteris paribus. In other words, as digitization increases by one per cent, export from Russia will tend to increase by the margin of about 7.42 per cent, all things being equal. This is consistent with the outcome of earlier researches. Increase in internet usage will reduce trade cost for Russia's exports, thus increasing the amount and quantity of export from Russia.

Based on different industry and as reported in appendix II, digitization has favored an increase in export for Crude materials, inedible, except fuels; and Machinery and transport equipment in the short-run, but encourages export for Beverages and tobacco in the long-run. Therefore, one would say that there is a prospect for an increase in trade as a result of digitization but that more reflective in the short-run. As the prospect for the effect of digitization is significant in export for some industries within the countries, it will advisable for the country to continue to appreciate and adapt to the use of current digital facilities to ensure a wholesome response to a surge in export from Russian Federation.

Table 4. MG short \& long-run estimation of digitization effect

\begin{tabular}{|c|c|c|c|}
\hline \multicolumn{2}{|l|}{ Short Run } & \multicolumn{2}{|l|}{ Long Run } \\
\hline Variables & Coefficient & Variables & Coefficient \\
\hline \multirow[t]{2}{*}{ ECT } & $-0.330 * * *$ & & \\
\hline & $(0.0860)$ & & \\
\hline \multirow{2}{*}{ D. $\ln G D P_{t}$} & $2.681 * * *$ & L2. $\ln G D P_{t}$ & $10.68^{* *}$ \\
\hline & $(0.645)$ & & (4.617) \\
\hline \multirow[t]{2}{*}{$D \cdot \ln \operatorname{In} t t_{t}$} & $0.0742 *$ & $\operatorname{lnIntt}_{t}$ & -1.627 \\
\hline & $(0.109)$ & & (1.602) \\
\hline \multirow{2}{*}{$D \cdot \ln F D I_{t}$} & 0.00207 & $L 2 . \ln F D I_{t}$ & 0.559 \\
\hline & $(0.0444)$ & & (1.268) \\
\hline \multirow[t]{2}{*}{$D \cdot \ln G I N I_{t}$} & -1.201 & $\ln G I N I_{t}$ & $6.466^{* *}$ \\
\hline & (1.073) & & (3.032) \\
\hline \multirow[t]{2}{*}{ Constant } & $-23.72 * *$ & & \\
\hline & (11.68) & & \\
\hline Observations & 198 & Observations & 198 \\
\hline
\end{tabular}

\subsection{Further Discussion: The Control Variables}

Trade literature as established that GDP is essential for the development of trade. The GDP reflects on the size of the market and its purchasing ability on the side of the importer while also demonstrating the ability to supply the size of the exporter. From the context of our estimation, the outcome demonstrates that the real GDP has a positive influence on export from the Russian Federation in both short-and Long-run. In the short-run, the coefficient is 2.681 and statistically significant at one per cent. This implies that as real GDP increases by one per cent, the export increases by 268.1 per cent all things being equal. On the other hand, with the coefficient of 10.68 and statistically significant at 5 per cent, it signifies that real GDP cause trade to increase by over 1068 per cent in the long-run, all things being equal. This has once again demonstrated the importance of GDP in international trade. At the industrial level there is a positive and statistically significant influence of GDP on export in the following industries; Crude materials, inedible, except fuels, Mineral fuels, lubricants and related materials, Chemicals and related products and Manufactured goods classified chiefly by material, howbeit, in the short-run. While in the long-run, there is no statistically significant coefficient of real GDP.

In overall, the influence of FDI on export from Russia is not statistically significant in both short-and long-run. Gini index is one of the innovative variables in the research. The Gini coefficient is an index aimed at assessing the degree of inequality in a distribution in a country. It measures the country's wealth or income distribution and how it deviates from an equal distribution. The assumption is that the as income is distributed equitably, it will aid export distribution as a more equable distribution of income could be associated with self-reliance. From the estimation 
herein, the impact of the Gini index is negative but not statistically significant in the short run. However, it has a high impact in the long-run with the coefficient of 6.466 which implies that as Gini index increases by one per cent, the export will surge by 646.6 per cent in the long-run, all thing being equal. However, in the industrial level, short-run coefficients are not statistically significant but the long-run coefficient of 4.632 for Mineral fuels, lubricants and related materials is statistically significant at 10 per cent.

\section{Conclusion}

The global economy is gradually turning to the digital economy owing to increasing usage and availability of the internet. In recent years, such usage has drastically risen and tremendously contributed to the growing globalization which brings the world together. Globalization enhances trade both in export and import and therefore, is seen to be a welcome development. As society continues to appreciate digital liberation, Russian federation has had some major setbacks in cyber-attacks which have deterred many from appreciating internet usage, especially before the current century. Given such mixed feeling in internet usage in Russia, one would wonder it if has any influence in its export and by extension if digitization has favored any particular industry with regards export from the country. This constitutes the focal research gap that is central to this research work.

To realize these objectives, digitization is a proxy with internet penetration rate. The constructed panel data is suitable for panel ARDL estimation method and the MG estimator was favored through a Hausman test. Its reveals that generally, digitization encourages export from the Russian Federation in the short-run but may not favorable in the long-run. In the short-run, digitization has favored export of Crude materials, inedible, except fuels; and Machinery and transport equipment but favorable to the export of Beverages and tobacco in the long-run. Hence, while the prospect of the effect of digitization is significant in this industries, it will advisable for the country to continue to appreciate and adapt to the use of digital facilities to ensure a wholesome increase in export from the country. This research is limited in two perspectives; it would be robust to use gravity model and digitization can also be capture by a number of digital transaction like the use of credit cards and wire transfers. This gives room for prospective researcher to exploit.

\section{References}

Abramova, N., \& Grishchenko, N. (2020). ICTs, Labour Productivity and Employment: Sustainability in Industries in Russia. Procedia Manufacturing, 43, 299-305.

Abramovsky, L., \& Griffith, R. (2006). Outsourcing and Offshoring of Business Services: How Important is ICT?. Journal of the European Economic Association, 4(2-3), 594-601. https://doi.org/10.1162/jeea.2006.4.2-3.594

Adeleye, N., \& Eboagu, C. (2019) Evaluation of ICT development and economic growth in Africa. Netnomics, 20, 31-53. https://doi.org/10.1007/s11066-019-09131-6

Azu, N. P. (2019). Trade realignment position in ECOWAS with gravity model. International Journal of Economic Policy in Emerging Economies, 12(2), 103-112.

Badjar, S., \& Rajeev, M. (2016). Contribution of Infrastructure to Output Growth in India. Emerging Economy Studies, (2), 240-252. https://doi.org/10.1177/2394901516661093

Baldwin, R. (2016). The Great Convergence: Information technology and the New Globalization. Harvard University Press, Cambridge.

Belderbos, R., \& Sleuwaegen, L. (1998). Tariff Jumping FDI and Export Substitution: Japanese Electronics Firms in Europe. International Journal of Industrial Organization, 16(5), 601-638.

Bojnec, S., \& Fertö, I. (2009). Impact of the internet in Manufacturing trade. Journal of Computable Information System, 50(1), 124-132.

Chavula, H. K. (2013). Telecommunications development and economic growth in Africa. Information Technology for Development, 19(1), 5-23. https://doi.org/10.1080/02681102.2012.694794

Choi, C. (2010). The effect of the Internet on service trade. Economics Letters, 109(2), 102-104. https://doi.org/10.1016/j.econlet.2010.08.005

Datta, A., \& Agarwal, S. (2004). Telecommunications and economic growth: a panel data approach. Applied Economics, 36(15), 1649-1654. https://doi.org/10.1080/0003684042000218552

Fink, C., Mattoo, A., \& Neagu, I. C. (2005). Assessing the impact of communication costs on international trade. Journal of International Economics, 67(2), 428-445. https://doi.org/10.1016/j.jinteco.2004.09.006

Freunda, C. L., \& Weinhold, D. (2004). The effect of the Internet on international trade. Journal of International Economics, 62(1), 171-189. https://doi.org/10.1016/S0022-1996(03)00059-X 
Freunda, C. L., \& Weinhold, D. (2004). The Internet and international trade on Service. American Economics Review, 92(2), 236-240.

Gromova, E., Timokhin, D., \& Galina Popova, G. (2020). The Role of Digitalisation in the Economy Development of Small Innovative Enterprises. Procedia Computer Science, 169, 461-467. https://doi.org/10.1016/j.procs.2020.02.224

Hausman, J. A. (1978). Specification Tests in Econometrics. Econometrica, 46(6), 1251-1271. https://doi.org/10.2307/1913827

Im, K. S., Pesaran, M. H., \& Shin, Y. (2003). Testing for Unit Roots in Heterogeneous Panels. Journal of Econometrics, 115(1) 53-74. https://doi.org/10.1016/S0304-4076(03)00092-7

Lin, F. (2014). Estimating the effect of the Internet on international trade, The Journal of International Trade \& Economic Development: An International and Comparative Review, 24(3), 409-428. https://doi.org/10.1080/09638199.2014.881906

Melitz, M. J. (2003). The Impact of Trade on Intra-Industry Reallocations and Aggregate Industry Productivity. Econometrica, 71(6), 1695-1725.

Pesaran, M. H., \& Smith, R. P. (1995). Estimating long-run relationships from dynamic heterogeneous panels. Journal of Econometrics, 68, 79-113.

Pesaran, M. H., Shin, Y., \& Smith, R. J. (2001). Bounds testing approaches to the analysis of level relationships. Journal of Applied Econometrics, 16(3), 289-326.

Pesaran, M. H., Shin, Y., \& Smith, R. P. (1999). Pooled mean group estimation of dynamic heterogeneous panels. Journal of the American Statistical Association, 94, 621-634.

Putilov, A. V., Pimenova, V. O., \& Timokhin, D. V. (2018). Infrastructural Support of The IT Economy of Russia and The Ways to Improve It. Procedia Computer Science, 145, 20-29. https://doi.org/10.1016/j.procs.2018.11.004

Raja, S., Imaizumi, S., Kelly, T., Narimatsu, J., \& Paradi-Guilford, C. (2013). Connectingtowork: How information and communication technologies could help expand employment opportunities. International Bank for Reconstruction and Development / The World Bank Washington DC.

Rauch, J. (1996). Trade and Search: Social Capital, Sogo Shosha, and Spillovers. NBER Working Paper No. 5618. Cambridge: National Bureau of Economic Research.

Rauch, J. E., \& Casella, A. (2003). Overcoming Informational Barriers to International Resource Allocation: Prices and Ties. The Economic Journal, 113(484), 21-42.

Sovbetov, Y. (2018). Impact of Digital Economy on Female Employment: Evidence from Turkey. International Economic Journal. https://doi.org/10.1080/10168737.2018.1478868

Sovbetov, Y., \& Saka, H. (2018). Does it take two to tango: Interaction between credit default swaps and national stock indices. Journal of Economics and Financial Analysis, 2(1), 129-149.

World Bank. (2018). Competing in the Digital Age: Policy Implications for The Russian Federation. Russia Digital Economy Report. International Bank for Reconstruction and Development / The World Bank. Washington DC, USA.

Yadav, N. (2014). The Role of Internet use on international trade: evidence from Asian and Sub-Sahara African Enterprises. Global Economic Journal, 14(2), 189-214. https://doi.org/10.1515/gej-2013-0038

\section{Note}

Note 1. The industries are: 1-Beverages and tobacco; 2-Crude materials, inedible, except fuels; 3-Mineral fuels, lubricants and related materials; 4-Animal and vegetable oils, fats and waxes; 5-Chemicals and related products, n.e.s.; 6-Manufactured goods classified chiefly by material; 7-Machinery and transport equipment; 8-Miscellaneous manufactured articles; 9-Commodities and transactions not classified elsewhere in the SITC. 


\section{Appendix A}

\section{Hausman Test for MG, PMG Decision (Export Model)}

\begin{tabular}{lllll}
\hline & Coefficients & & & \\
\cline { 2 - 5 } & (b) & (B) & (b-B) & sqrt(diag(V_b-V_B $))$ \\
& MG & PMG & Difference & S.E. \\
\hline $\ln$ GDP & 4.372937 & 1.191139 & 3.181798 & 0.570871 \\
$\ln$ Intt & -0.3022961 & -0.136239 & -0.43858 & 0.1010479 \\
$\ln$ FDI & 0.1533062 & 0.3966464 & -0.2433403 & 0.074059 \\
$\ln$ Gini & -2.387071 & 0.1675977 & -2.219474 & 3.070125 \\
\hline
\end{tabular}

Note: $\mathrm{b}=$ consistent under Ho and Ha; obtained from xtpmg

$\mathrm{B}=$ inconsistent under Ha, efficient under Ho; obtained from xpmg

Test: Ho: difference in coefficients not systematic

$\operatorname{chi} 2(3)=(b-B)^{\prime}\left[\left(\mathrm{V} \_b-V \_B\right)^{\wedge}(-1)\right](b-B)=91.91$

Prob $>$ chi2 $=0.000$

\section{Appendix B}

MG Short \& Long-Run Estimation of Digitization Effect on Industrial Export

\begin{tabular}{|c|c|c|c|c|c|c|c|c|c|}
\hline & $(1)$ & $(2)$ & (3) & (4) & $(5)$ & $(6)$ & (7) & (8) & (9) \\
\hline VARIABLES & \multicolumn{9}{|c|}{ Short Run Estimation } \\
\hline \multirow[t]{2}{*}{ ECT } & $-0.748 * *$ & -0.416 & $-0.533 * *$ & -0.278 & -0.130 & -0.0932 & $-0.609 *$ & -0.0132 & -0.150 \\
\hline & $(0.348)$ & $(0.295)$ & $(0.263)$ & $(0.325)$ & $(0.294)$ & $(0.310)$ & $(0.314)$ & $(0.281)$ & $(0.220)$ \\
\hline \multirow{2}{*}{ D. $\ln G D P_{t}$} & -0.838 & $3.079 * *$ & $4.056 * *$ & 3.186 & $5.657 * * *$ & $2.798 * * *$ & 1.015 & 1.242 & 3.937 \\
\hline & $(1.796)$ & $(1.392)$ & $(1.782)$ & $(3.599)$ & (1.637) & $(1.075)$ & $(1.373)$ & $(1.976)$ & $(2.930)$ \\
\hline \multirow[t]{2}{*}{ D. $\ln \operatorname{In} t t_{t}$} & -0.513 & $0.138^{*}$ & -0.0435 & 0.281 & 0.471 & 0.534 & $0.0221 *$ & -0.171 & -0.0505 \\
\hline & $(0.356)$ & $(0.380)$ & $(0.318)$ & $(0.885)$ & $(0.359)$ & $(0.327)$ & $(0.352)$ & $(0.458)$ & $(0.675)$ \\
\hline \multirow[t]{2}{*}{$D \cdot \ln F D I_{t}$} & 0.00826 & -0.0441 & $-0.103 *$ & -0.0693 & -0.0810 & -0.0460 & -0.0353 & 0.0543 & $0.335 * *$ \\
\hline & $(0.0696)$ & $(0.0672)$ & $(0.0622)$ & $(0.171)$ & $(0.0619)$ & $(0.0508)$ & $(0.0679)$ & $(0.0972)$ & $(0.144)$ \\
\hline \multirow[t]{2}{*}{$D \cdot \ln G I N I_{t}$} & 0.536 & 0.371 & 0.850 & -6.949 & -2.261 & -2.181 & 0.00786 & 3.641 & -4.826 \\
\hline & $(3.026)$ & $(2.523)$ & $(2.454)$ & (6.779) & $(2.483)$ & (1.969) & $(2.533)$ & $(3.742)$ & $(5.730)$ \\
\hline \multirow[t]{2}{*}{ Constant } & 43.95 & $-57.73 *$ & -1.391 & -1.716 & $-60.14 *$ & -38.14 & -17.81 & -17.92 & -62.57 \\
\hline & $(49.25)$ & $(30.68)$ & $(32.99)$ & $(85.10)$ & $(31.49)$ & $(23.93)$ & $(30.35)$ & $(43.70)$ & $(64.85)$ \\
\hline VARIABLES & \multicolumn{9}{|c|}{ Long Run Estimation } \\
\hline \multirow[t]{2}{*}{$L 2 . \ln G D P_{t}$} & -1.812 & 5.383 & 0.221 & -0.0382 & 16.19 & 14.43 & 1.882 & 41.41 & 18.44 \\
\hline & (3.118) & (4.099) & (2.178) & (11.38) & (38.60) & (45.94) & (1.864) & $(865.2)$ & $(30.02)$ \\
\hline \multirow[t]{2}{*}{$\operatorname{lnIntt}_{t}$} & $0.904 * *$ & -0.307 & 0.332 & 1.506 & -1.190 & -0.213 & 0.110 & -14.19 & -1.597 \\
\hline & $(0.421)$ & $(0.409)$ & $(0.282)$ & $(2.146)$ & $(3.551)$ & $(1.373)$ & $(0.243)$ & $(306.5)$ & (3.159) \\
\hline \multirow[t]{2}{*}{$L 2 . \ln F D I_{t}$} & 0.0441 & -0.385 & 0.173 & -0.559 & -1.084 & -2.096 & -0.219 & 10.52 & -1.362 \\
\hline & $(0.186)$ & $(0.406)$ & $(0.191)$ & (1.237) & $(2.965)$ & $(7.353)$ & $(0.168)$ & (228.3) & $(2.558)$ \\
\hline \multirow[t]{2}{*}{$\ln G I N I_{t}$} & 2.252 & 5.821 & $4.632 *$ & 9.707 & 16.52 & 21.56 & 1.308 & 6.504 & -10.11 \\
\hline & (2.187) & (3.894) & $(2.500)$ & (20.17) & (39.67) & $(65.26)$ & (2.101) & $(247.1)$ & $(24.00)$ \\
\hline Observations & 198 & 198 & 198 & 198 & 198 & 198 & 198 & 198 & 198 \\
\hline
\end{tabular}

Note: 1-Beverages and tobacco; 2-Crude materials, inedible, except fuels; 3-Mineral fuels, lubricants and related materials; 4-Animal and vegetable oils, fats and waxes; 5-Chemicals and related products, n.e.s.; 6-Manufactured goods classified chiefly by material; 7-Machinery and transport equipment; 8-Miscellaneous manufactured articles; 9 -Commodities and transactions not classified elsewhere in the SITC. Standard errors in parentheses; $* * * \mathrm{p}<0.01, * *$ $\mathrm{p}<0.05, * \mathrm{p}<0.1$.

\section{Copyrights}

Copyright for this article is retained by the author(s), with first publication rights granted to the journal.

This is an open-access article distributed under the terms and conditions of the Creative Commons Attribution license (http://creativecommons.org/licenses/by/4.0/). 